\title{
Risk and Disability: Towards a Reflexive Theory
}

\author{
Jason L. Powell* \\ Department of Social and Political Science, University of Chester, CH1 4BJ, United Kingdom
}

*E-mail address: Jasonpwll3@gmail.com

\section{ABSTRACT}

This paper analyses the concept of 'risk', which both as a theoretic modern society, is slowly being developed within the humanistic and soci Notwithstanding this, the concept of risk and the meaning and implicatio ed with have not been fully explored in relation to disability. Risk is shrouded in hist cal and co mpe ary political debate about whose 'role' and 'responsibility' is it for 'disability' in iety - does reside with the state or the individual?

Keywords: Risk; Disability; Theory; Policy

\section{INTRODUCTION}

The article begins by examining some the a guments put forward by Ulrich Beck (1992) and the relevance of the underst nding how changes in modern society have shaped the welfare identities disa ed peop c. To illustrate this, the article reviews the historical rise and consolid on are in the United Kingdom. The article assesses how risk has impinged changins rms and modern practices of the 'welfare state'. From this, the article traces no ffare tran mations to what can be defined as the 'risk society' (Beck 1992) and the npac this on identity in disability formations and key areas such as the relationship of disabled ped 10 the state (Cartmel and Furlong, 1997; Epstein, 1998).

The art 'e the noves to assessing neo-liberalism as a key feature of the 'risk society' and the re-pos ng of sabled people as 'consumers' and welfare agents as 'managers'. The artict then tyates the implications of neo-liberal social policy for disabled people and prof ssion practic sy using the 'risk' framework derived from the work of Ulrich Beck

\section{TRANS, ORMING AGE}

As a starting point we should note the dramatic change in the institutional structure that has underpinned definitions of age identities. In this context it is important to highlight the way in which ageing identities were transformed in the two decades following the ending of the second world war (Phillipson 1998). The key development here concerned the way in which, in advanced capitalist societies, disability was transformed by the social and economic institutions associated with the welfare state, such as education, training and work (Fornas 
and Bolin, 1995). These became crucial in shaping the dominant discourse around which disability was framed, and the identities associated within and across the lifecourse (Epstein, 1998). A supporting theme was the re-ordering of the lifecourse into distinctive stages associated with education, work and retirement, with transition to retirement becoming an important element in the development of a new identity separate from that associated with disability, work and paid employment (Best 1980).

On this last element, the debate in the 1940s and 1950s focused on the need to escape the injustice and deprivation endured in the economic depression of the 1930s (Frith, 1984). Hence, what has been described by one historian of social policy (Rodney Lowe) as the role of the welfare state in moving society to a higher ethical ground. Lowe (1993: 21, sugg in fact that the welfare state was seen as being able to: '... elevate society by ins tionalisin deeper sense of community and mutual care'.

Disabled people were integral to this theme of a more inclusive sc ciety one rinc to erase the link between disability and images of poverty (Hall et al. 1 78). T) possit rty of transforming age, through more secure provision of education and ran was a gnificant component of the post-war social contract. Education for disable people viev ed, first, as a fair exchange for work and income. Second, in rhetorical to in a meas of the way in which disabled people were now protected from the hazas of ial inequality. Third, as part of the intergenerational contract and indicative close raintained between family groups, disabled and older (Arber and Attias- -

If the welfare state created -or set out to creat a new iden ity for disability, it was the transformation in welfare from the 1980s onwards a posed new challenge to the status and identity of disabled people. The crisic in disab took hold from this period reflected, to a significant degree, the loosen the institutional supports underpinning the life course. Disabled people were themse es cation of modernity, reflecting the achievements of industrialism, impraved pub education and the growth of social welfare (Powell and Edwards, 2002). T/ Sto y grow in the proportion of disabled people in the UK population was, up until beg aning of ne 1980s, largely contained within the dual institutions of education an

These, along with ties ma ined between generations, created a social, economic and moral space with $n$ growin numbers of disabled people could be channelled and contained. In thingard, cation and work was predominantly a state of affairs for disabled people may be seen as curate in at least two senses: first, in terms of the way that resources $\mathrm{W}$ distr ted; selond, in relation to the identities and forms of surveillance created. For a d of 20 ears or more, moving disabled people into the zone of work from educati eld a th underlying issue of securing a place and identity for aging within the ame rk of an avanced capitalist society. The meaning of disability was, temporarily

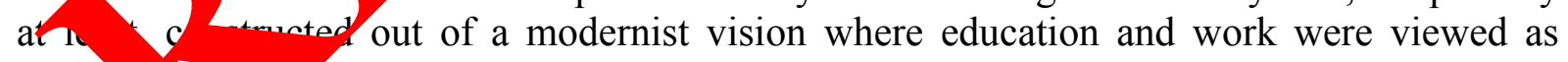
"natura points in the human life cycle.

Tho avelling of these arrangements can be traced to at least three types of crisis affecting the management of disability in the last quarter of the twentieth century: economic, social and cultural. The economic dimension has been well-rehearsed, with successive crises from the mid-1970s onwards undermining, first, the goal of full employment (and hence destabilising retirement), and, second, the fiscal basis of the welfare state (accelerated with the onset of a privatisation from the 1980s onwards) (Powell and Edwards, 2002).

These aspects led to the development in the social sphere of what to paraphrase Carroll Estes et al (2001) refers to as the 'crisis construction' and 'crisis management' of disability, with disability now socially constructed as a "problem" for society (Cartmel and Furlong, 
1997). At its most extreme, demographic change was itself now viewed as a source of the economic crisis, notably in respect of the apparent imbalance between 'productive' and 'nonproductive' sectors in the economy (Longman 1987). Finally, at a cultural level, the modern life course itself came to be viewed as playing a contributory role in the alienation of disabled people in western society.

The sense of unease about the nature of demographic change itself chimed in with a wider discourse about wider developments accompanying the transition from a modern to a postmodern world (Conrad 1992). Uncertainties about the benefits of aging are certainly nothing new. Revisionist accounts of the place of disabled people in past societion have tended to emphasis the punitive character of economic relief, and the marginalis? an on lacking gainful employment (Hall et al. 1982). Both aspects may be foun signific. elements in present-day society, for example in the undermining of education an he assa on minimum wage amidst fears of 'too few workers' over an 'excess' $\alpha$ pensioner vinc nt 1999). But these historical continuities are given added emphasis in a stmod age.

Arguably, disabled people have the most to lose given the re ru $\mathrm{g}$ of re tionships associated with postmodernity. The extension of individualizati n may, to ke or example, be perceived as highly threatening to identity in the beginn ase of th ce-course. As Giddens (1991) argues, modern life raises at least tyo poss ties: the promise of a multiplicity of identities on the one side, and the dange or alologica cecurity on the other. Similarly, Biggs (1993) suggests that in response t these circumsta, ces, individual actors will attempt to find socially constructed spaces t lend som form of predictability to everyday relationships. Yet in a postmodern world spaces hay be increasingly difficult to locate.

\section{FROM WELFARE STATE TORISK SC IETY}

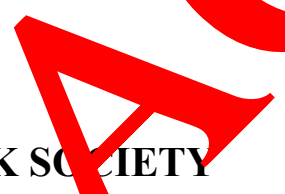

From the 1980s onward he cr is affect ng youh illustrated the way that the problem

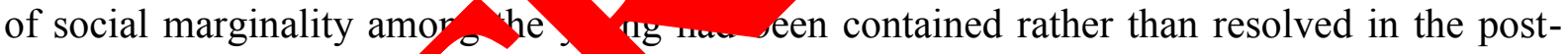
war period. Moreover hat a pos dern setting did have to offer -namely the ideal of consumption replacip th. f product n- seemed only to further marginalise groups such as disabled people. B unan, fo, ample, writes of the accelerating emancipation of capital from labour produci g a situation in ce: 'instead of engaging the rest of society in the role of producers, $\mathrm{c}$ tal te to engage them in the role of consumers' (Bauman 1992: 111). This transformation act refle ts a more general shift from the public provision characteristic of what and $v$ a87) refer to as 'organized capitalism', to the more flexible arra geme s runnin angh the period of 'disorganised capitalism'.

This an disa person. In the conditions of advanced modernity, growing up moves from being a collective 1 individual experience and responsibility. The notion of an aging society (with social obligations) becomes secondary to the emphasis on the way in which families and disabled individuals handle the demands associated with population aging.

This new development may be seen as a characteristic of a society where the 'social production of risk' runs alongside that associated with the 'social production of wealth' (Beck 1992). As already argued, improved life expectancy may itself be viewed as a consequence of the social transformations associated with modernization. Beck (1992: 21) defines the nature of risk as a 'systematic way of dealing with hazards and insecurities induced and introduced by modernization itself' (author's emphasis). Of course, disabled people have been ever- 
present in human history. But to paraphrase Beck, in the past these could be seen as personal rather than societal tragedies (or achievements). The impact of disabled people was limited both by their lack of demographic presence compared to older people and, crucially, by the relatively superficial nature of the category of 'problem delinquent' or 'anti-social young person' (Jefferson, 2000). The changes consequent upon modernisation transformed both these elements, with disability becoming a new and socially recognised risk.

But in line with Beck's thesis about the nature of risk society are three main developments running through an understanding of disability. First, the globalisation of disability is increasingly recognised-all societies (poor as well as rich) are undergoino aimilar population transformations (albeit with notable exceptions such as those devastated by the AIDS virus). Disability thus becomes simultaneously botb event and one shared with different cultures and societies across the globe.

Second, disability experiences are themselves hugely (and increasingly) dives Un er the guise of the welfare state, growing up was compressed into a irly l ited ro ge of institutions and identities (notably in respect of income and lifesty s). vility it the postwelfare society, however, has substantially expanded in respect i social o rtun ies as well as new inequalities and divisions (Cartmel and Furlong, 1997 ent 1995).

Third, disability is also being changed by what the la Ulrio leck (1992) describes as the era of reflexive modernization. This may be concei oun terms or windividuals and the lay public exert control and influence on the shape ind character of hodernity. At its core, Beck's (1992: 10) approach suggests the thesis that the more pcieties are modernised, the more agents (subjects) acquire the ability to refl upon th social conditions of their existence and to change them in that way'. Eor disable this highlights the move from conditions of structured oppression towards cibility of new, consumer-based lifestyles (Fornas and Bolin, 1995). On the other hand, his itm certainly goes hand-in-hand with the marginalisation of significant grouns of disabl people, trapped in the contradiction between decreasing personal incomes ( $\mathrm{i}$ com and sa ings) and the steady withdrawal of support from the state for their future ion ovision (Sowell, 2001).

These developments fin esumoness of the challenge facing disabled people. In reality in terms of th social $\mathrm{p}$ ion, the young have moved into a new 'zone of indeterminacy' whic' is rginal to work and welfare (Epstein, 1998). Disabled people experience the wo-d culy as ough they were riding (as Giddens 1991,28 expresses it in his description of 1 gh modernity) Juggernaut': '...it is not just that more or less continuous and profoun roces of charge occur; rather, change does not consistently conform either to human expe on, or to human control'. This may seem a relatively abstract description of the cric hich a led people may experience but it rather accurately conveys the reality of wha may ppen to abled people in situations of rapid change.

\section{RISK, YF-AUTONOMIZATION AND MANAGING OLD AGE: A POST- WELF ARE SOCIETY?}

Disability is itself becoming a more social, reflexive and managed process, notably in the relationships between the individual, the state and a range of public as well as private services; this involves the 'political domain'. Coupled with this, processes and relationships in the management of disability are decided by political rationalities (neo-liberalism) that are bound up with ideological and philosophical questions of self-governance and autonomy. Neo-liberalism considers that a welfare society must reflect only the interplay of social and 
political structures forged out of self-responsibility and consumerism (Leonard 1997; Powell 2001). In recent years, disabled people as autonomous consumers derive their 'education', individually and collectively, from a range of social policies, institutions and sites, so that the organisation of education involves market forces, schools, state and families.

The neo-liberal dominance in social policy has been successful because it has identified existential concepts such as self-responsibility, self-governance and self-care that are said to facilitate human action (Leonard 1997). The regulation of personal conduct has shifted from being presented as a responsibility of the state to the responsibility of micro-level social actors such as 'professional experts' and 'disabled people' as 'consumers' (Epstein, 1900-The implications are profound. As Nikolas Rose (1996: 59-60) has pointed out:

' $\ldots$ the disadvantaged individual has come to be seen as potentially and 1 ly an act agent in the fabrication of their own existence. Those 'excluded' from the beneh a life choice and self-fulfilment are no longer merely the passive suppor of a set so al determinations: they are people whose self-responsibility aspirations ve be defor $c \mathrm{~d}$ by the dependency culture, whose efforts at self-advancement have $b$ on ated... be assisted as active citizens [through] programmes of emp werment enab them to assume their rightful place as the self-actualizing and dema a subjects an 'advanced' liberal democracy'.

Here neo-liberalism attempts to define the social domain inerpret valid human needs. Under neo-liberalism, the state re-invents it tf and its welfar subjects based upon minimal intervention and regulation via a rolling $\mathrm{p}$ gram of pri atization, deregulation, and contraction of welfare services (Estes et al. 2001). ' ithin the 'mixed economy of welfare', there has been the social construction of a market- orie. delivery of education and the role of disa aple as consumers. As Leonard (1997) claims the neo-liberal state is being reorgan zed w Iude retention of a strong centre to formulate policy but the dissemination of esponsibility for policy implementation to managerial regimes. As Gordon 199, 36) poil sout:

'The fulfilment of the $1 \mathrm{j}$ ' ide 2 . is a r casting of the interface between the state and society to one of market der. ucum the ambition of neo-liberalism to implicate individuals as players in the marko 'me administered by actors'.

Management a an ninistrati power (cf. Habermas 1992) has been presented as consolidating ne 'yoralish 'y adding 'choice' and reducing 'risks' and 'problems' associated witb disabled peopl 1 education system in UK: a move away from the state as education $p$ rider schooing subjects" to a managerial one of "monitoring" and "assessment" h-libera narket economy (Fornas and Bolin, 1995).

noven ay ay from a traditional local authority role of implementing state edy ation an actur al and privatised role of 'management' is a feature of the risk society "tea "g focins" have had their knowledge base transformed from philanthropic 'teach 'o 'manager' of budgets, audits and accounting systems ((Fornas and Bolin, 1995). In emerg neo-liberal managerial regimes, judgement is increasingly bound up with managerial imperatives concerning risk assessment, corporate objectives, purchasing and resource control ((Fornas and Bolin, 1995). The devolution of managerial responsibilities is intended to empower disabled individuals and to constrain professional autonomy by having such c managers internalize budgetary disciplines and translate social policy imperatives (Leonard 1997).

These imperatives have had a major impact upon social policy and disability. Such neoliberal reforms were about recasting disabled people as consumers in a market place to be managed by managerial regimes (Powell 2001; cf. Habermas 1987). Education management 
as an administrative power are also 'risk-assessors' and 'enforcers' of the mixed education economy, a discourse that leaves disabled people who engage in 'education market', on the contradictory and "risky" ground of being simultaneously 'consumers' and potential 'problems' individuals (Biggs and Powell 2001; Powell and Biggs 2000).

Furlong and Cartmel (1997) argues that neo-liberalism consistently equates selfresponsibility with freedom, with disabled people presented as active agents in a consumer market. However, divisions associated with class, gender and ethnic position may still leave many poorer disabled people highly vulnerable - despite the neo-liberal vision of the 'responsible consumer'. Gendered inequalities may be especially important in this comario. As Nancy Fraser suggests:

'Participants in the 'masculine' subsystem are positioned as right-beari beneficiar and purchasing consumers of services. Participants in the 'feminine' subsy tem, the oth hand, are positioned as dependent clients' (1987: 113).

\section{CONCLUSION}

By constituting risk as a centrally defining motif of "la modernity" this article contributes to new perspective for "critical sociology or sability bis article has raised questions about the historical and contemporary un lerstanding of so-ral forces that are an important qualification in understanding the $\mathrm{s}$ fting disco rses associated with the transformation from the welfare state to the risk sod Disabl d people it might be argued are affected by two major changes in respact of acce. pport on the one side, and the construction of identity on the other. On the de there is the creation of 'no care' zones where community supports may disintegrate $n t^{b}-1$ of inadequate services and benefits. On the other side, there may equally he the em gence of 'No Identity Zones', these reflecting the absence of spaces in which $\checkmark \mathrm{co}$, ruct a able identity for disabled people (Phillipson and Biggs 1999).

The argument here is now being experienced in a new and somewhat distinctive way by disa d people. arginality, for much of the post-war period, could be reclaimed through id ht construct $d$ out of an emerging consensus regarding education and social welfare a nas a. Golin, 1995). The collapse of this consensus has exposed once again the vulne able status of abled people. But this vulnerability is not just about the material exp ence deprivation, it also reaches into the texture of day-to-day living. For more affluent $s$ s, a ter porary solution seems to have been found in the the promotion of new lif es. Th ocia and existential vacuum which this suggests reinforces the sense of unc taint bout th dentity of disabled people (Epstein, 1998). The great advantage of the loos ing assibility of an alternative social and politic. onstruction of disability beginning to emerge which might move beyond welfare structures $2 \mathrm{~d}$ on assumptions of dependency. This new politics would present a challenge to the consiraints placed upon lifecourse development for disabled people and opportunities for meaningful agency without losing sight of the social threats posed by new forms of risk and insecurity.

\section{Biography}

Hon Professor Jason L. Powell BA (Hons), MA, Ph.D, FRSA is University Lecturer, Honorary Professor and Adjunct Professor. He is formerly Professor of Social Gerontology and Associate Dean of Faculty of Health 
and Life Sciences at University of Coventry. He holds an Honorary Fellowship at University of Liverpool; Honorary Professor at Australia-Asia Research and Education Foundation at Tasmania University; Visiting Research Fellow at Oxford; and recently invited as Visiting Scholar at Harvard University. He has been Visiting Professor in Canada, US, Australia, Africa and Jordan. He was nominated and elected to Fellowship of the British Royal Society of Arts (FRSA) in recognition of his research. He has strong interests in social theory, ageing, power and identity. He is author of Social Theory and Ageing (2006) which was part of Charles Lemerts distinguished „New Social Formations book series, Rowman and Littlefield: New York.

\section{References}

[1] Arber, S. and Attias-Donfut C., 2000. The Myth of Generational Conflict ondon: Routledge.

[2] Bauman, Z., 1992. Intimations of Postmodernity. London: Routle age \& Kegan

[3] Beck, U., 1992. Risk Society. London: Sage.

[4] Best, F., 1980. Flexible Life Scheduling. New York: Pr

[5] Biggs, S. 1999. The Mature Imagination. Milton Ke nus: OU

[6] Biggs, S. 2000. "Elder Abuse and Surveillance The Rationalities and Technologies of Community Care", Journal of Contemporary alth, 4: 43-99.

[7] Biggs, S. and Powell, J.L. 2001. "A Foucauldia alvsi of Old Age and the Power of Social Welfare", Journal of Aging \& S Policy 12:93-111.

[8] Delanty, G. 1999. Social Science: Beyon Vonsty ctivism, Sage: London.

[9] Department of Health, 198 Ca $g$ for $P$ ople: Community Care in the next Decade and Beyond, Cmnd. 849 ando HMSO.

[10] Department of Hea' h, 1994. 'S Hospital Activity Statistics: England 1983-94 Statistical Bulle $n$. ndon: De ${ }_{1}$ tment of Health.

[11] Estes, C. ar ssociates 01. Social Policy and Aging. Thousand Oaks: Sage Books.

[12] Epstei 1998 isahility Culture: Identity in a Postmodern World, Blackwell.

[13] Frith S 19 The So ciology of Disability, Causeway.

[14 Forn , J and b sin, G 1995 Disability Culture in Late Modernity, Sage.

[15] ong, A and Cartmel, F (1997) Young People and Social Change, Routledge

[16] Fraso N. 1987. "Women, welfare and the politics of need interpretation", Hytapia: A Journal of Feminist Philosophy, 2: 102-121.

[17] Giddens, A., 1991. The Consequences of Modernity. Oxford: Polity Press.

[18] Gilleard, C., and Higgs, P., 2000. Cultures of Ageing: self, citizen and the body. London: Prentice-Hall. 
[19] Gordon, C 1991. "Governmental rationality: an introduction”, Pp.1-51 in G. Burchell, C. Gordon and P.Miller (Eds.) The Foucault Effect: Studies in Governmentality, Chicago: Chicago University Press.

[20] Habermas, J. 1992. Postmetaphysical Thinking, Cambridge: polity press.

[21] Leonard, P., 1997. Postmodern Welfare. London: Sage.

[22] Lowe, R., 1993. The Welfare State in Britain since 1945. London: Macmillan.

[23] Minkler, M and Estes, C. (eds.). 1998. Critical Gerontology: Perspectives fron Political and Moral Economy. New York: Baywood.

[24] Otway, H., B. Wynne, 1989. Risk Communication: Paradigm and Parado. Analysis, 9: 141-145.

[25] Phillipson, C. 1998. Reconstructing Old Age, London: Sage B

[26] Phillipson, C. and Biggs, S. 1999. "Population Ageing: cri cal geron sociological tradition". Education and Ageing, 14: 159

[27] Powell, J.L. 2001. "Theorizing Gerontology: The $C$ of Old Professional Power and Social Policy in the Un ed Kingdom", Jo rnal of Aging \& Identity, 6: 117-135.

[28] Powell, J.L. and Biggs, S. 2000. "Managing Ol ge: The Sisciplinary Web of Power, Surveillance and Normalisation", Jou al of Agin dentity, 5: 3-13.

[29] Rose, N. 1996. "Governing advanced li eraly acies". Pp.37-64 in Barry, A, Osborne, T., and Rose, N. (Eds.) Foucan and Pslitical Reason, Chicago: Chicago University Press.

[30] Stearns, P., 1977. Old ga Ev Casty: The Cance. London: Croom Helm.

[31] Townsend, P. a derburn D, 1965. The Aged in the Welfare State. London: Bell.

[32] Vincent, J 195. Inequ af Old Age. London: UCL Press.

[33] Vince $19^{\circ}$ Politics, Power and Old Age. Buckingham: Open University Press.

[34] Wunne, B., 87. R,k Management and Hazardous Waste. Berlin: Springer.

[35 Arbe S and G an, J (1995) Connecting Gender and Ageing. OUP: Milton Keynes

[36] on, J.C.\& Rosenbaum, M. (2004) "Nice to Know You? Testing Contact, Cultural, and oyp Threat Theories of Anti-Black and Anti-Hispanic Stereotypes," Social Scien Le Quarterly, 85 (June 2004), 257-284

[37] Espenshade, T and Chang C. (2005) "The Opportunity Cost of Admission Preferences at Elite Universities", Social Science Quarterly 86 (2), 293-305

[38] Estes, C, Biggs, S and Phillipson, C (2003) Social Policy, Social Theory and Ageing. Open University Press: Milton Keynes

[39] Giddens, A (1993) Sociology. Polity Press 
[40] LeFevre, J. (2003) "The Value of Diversity: A Justification of Affirmative Action," Journal of Social Philosophy, 34 (March 2003), 125-133.

[41] Powell, J (2005) Rethinking Social Theory and Later Life. Nova Science: Nova

[42] Phillipson, C (1998) Reconstructing Old Age, Sage: London

[43] Sander, R. (2004) "A Systemic Analysis of Affirmative Action in American Law Schools" 57 Stanford Law Review 367 (2004).

[44] Sowell, S (2004). Affirmative Action Around the World: An Empirical Study Haven, Connecticut: Yale University Press, 2004

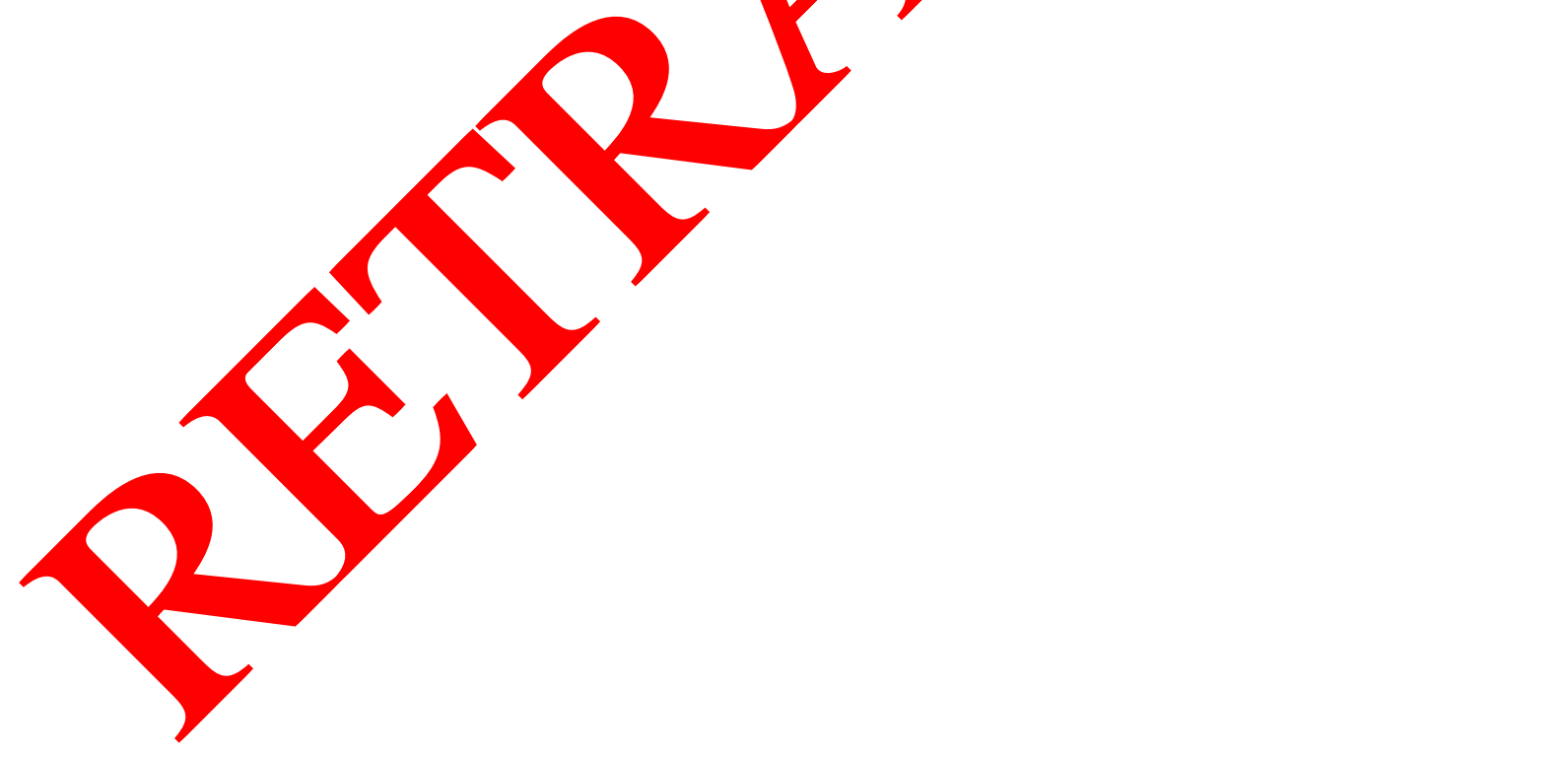

